\title{
Influence of the thermal environment on the stingless bee foraging activity: a mini-review
}

João Batista Freire Souza-Junior ID. João Paulo Araújo Fernandes de Queiroz ID. Cheyla Magdala de Sousa Linhares

JBF Souza-Junior (Corresponding author)

Laboratory of Biometeorology and Environmental

Biophysics, Universidade Federal Rural do Semi-Árido

(UFERSA), Mossoró, Brazil.

email: souza.jr@ufersa.edu.br
JPAF Queiroz

Universidade Federal do Ceará (UFC), Department of Animal Science, Fortaleza, Brazil.

CMS Linhares

Department of Agrarian Sciences, Universidade Federal Rural do Semi-Árido (UFERSA), Mossoró, Brazil.

Received: October 30, 2018 - Revised: December 30, 2018 • Accepted: January 10, 2019

\begin{abstract}
In tropical environments, stingless bees are an important group of pollinators, helping to maintain plant biodiversity and, consequently, to preserve ecosystems. The foraging activity of these insects is influenced by biotic and abiotic factors. Although air temperature limits activities outside the hive, the natural thermal environment is complex; meteorological variables interact with each other, requiring elaborate thermoregulatory responses from bees. The complexity of the thermal environment has been the subject of recent research on insect thermoregulation. The effects of wind and especially solar radiation should be considered when studying the behavior of stingless bees. In this context, this mini-review aimed to address the main components of the thermal environment that influence the foraging activity of stingless bees.
\end{abstract}

Keywords: air temperature, daily rhythm, seasonality, solar radiation, thermal challenge, thermoregulation

\section{Introduction}

Pollinators, essential to the balance of ecosystems, have been undergoing a global decline, accompanied by the decline of plant species with which they maintain a relationship of dependence (Potts et al 2010). In Brazil, there is hard evidence that habitat loss, invasion of exotic species and climate change have been reducing native bee populations (Giannini et al 2012). These social insects are widely distributed in tropical regions (Cortopassi-Laurino et al 2006), acting as pollinating agents and assisting in the maintenance of plant biodiversity of ecosystems (Slaa et al 2006). In addition, they are effective pollinators of numerous agricultural crops (Giannini et al 2015).

Climate changes that have been occurring in the last decades and those projected for the next decades have provided extreme conditions for animal survival (Abecia et al
2017; Rashamol et al 2018), negatively affecting their performance and health.

In social bees, the foraging activity rhythm occurs according to weather conditions, especially temperature (Roubik 1989; Oliveira et al 2012; Jaapar et al 2018). However, although the air temperature is the main meteorological variable influencing the behavior and thermal status of foraging bees, studies have shown the importance of other abiotic factors in insect thermal dynamics, especially solar radiation (Figure 1; Kovac et al 2010; Stabentheiner et al 2012).

Based on this thermally challenging scenario that stingless bees face in a highly variable environment, this minireview aimed to address the main components of the thermal environment that influence the foraging activity of stingless bees.

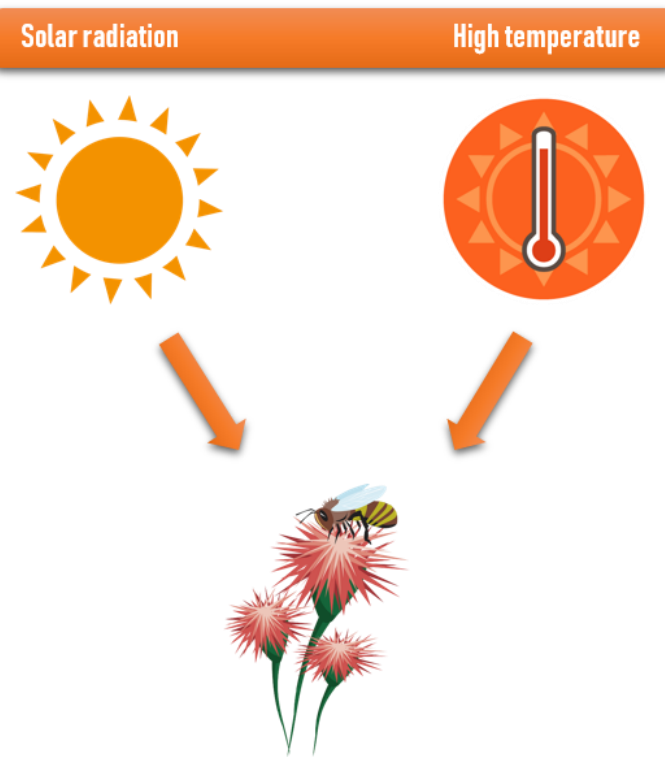

Figure 1 Main components of the thermal environment that cause changes in the stingless bees foraging. 


\section{Temperature}

Although their body temperature is influenced by the thermal environment inside and outside the hive, social bees are not thermoconformists. One of the behavioral adaptations of Melipona subnitida, for example, main native species of the Brazilian semi-arid, is the concentration of collecting activities in the temperature range between 22 and $34{ }^{\circ} \mathrm{C}$ (Maia-Silva et al 2015). Environmental temperatures above 34 ${ }^{\circ} \mathrm{C}$ are tolerated when these stingless bees have water to perform evaporative cooling (Ferreira and Hrncir 2012), keeping their body temperature below the lethal temperature $\left(48,0^{\circ} \mathrm{C}\right)$, even when exposed to effective temperatures up to $50{ }^{\circ} \mathrm{C}$ during foraging (Hrncir et al 2015).

The air temperature varies throughout the day and according to the season. Layek and Karmakar (2018) and Macías-Macías et al (2017) found significant effects of time of day, weather variables and seasonality on the foraging activity of stingless bees Trigona iridipennis in India and Melipona colimana in Mexico, respectively. In this study by Layek and Karmakar (2018), maximum values of foraging bees were observed between 9:00-11:00 and 15:00-16:00, with maximum activity in spring, attributing these differences to ambient temperature variations and to the availability of floral resources, which are dependent on the time of day and season. Basari et al (2018) and Jaapar et al (2018) showed that foraging activity of stingless bee Heterotrigone itama decreases when the air temperature rises near noon.
Additionally, recent studies have also shown that stingless bees can have one or more times when foraging reaches its peak (Barbosa et al 2016; Layek and Karmakar 2017; Basari et al 2018).

At very low temperatures, foraging of Melipona subnitida does not occur, even when profitable pollen sources are available (Maia-Silva et al 2014). Pollen collection time for this same bee species is influenced by high temperatures associated with natural resource availability (Maia-Silva et al 2015).

\section{Solar radiation}

Another abiotic factor determining the success of foraging activity is global solar radiation because, in an environment of the high solar radiation incidence, such as the Caatinga biome, for example, this environmental factor cannot be neglected. Studies conducted in the semi-arid region of northeastern Brazil found results for global solar radiation levels above $1000 \mathrm{~W} / \mathrm{m}^{2}$ from 10:00 to 14:00 (Da Silva et al 2010). Oliveira et al (2014) found values between 100 and 800 $\mathrm{W} / \mathrm{m}^{2}$ at times where bee foraging activity still occurs at a higher intensity (5:30 to 9:00).

Souza-Junior (2019) found similar relationships between the number of foraging bees, environmental temperature and solar radiation (Figure 2), where there was a decrease in the foraging activity when the temperature was above $30.0{ }^{\circ} \mathrm{C}$ and when solar radiation exceeds $800 \mathrm{~W} / \mathrm{m}^{2}$.
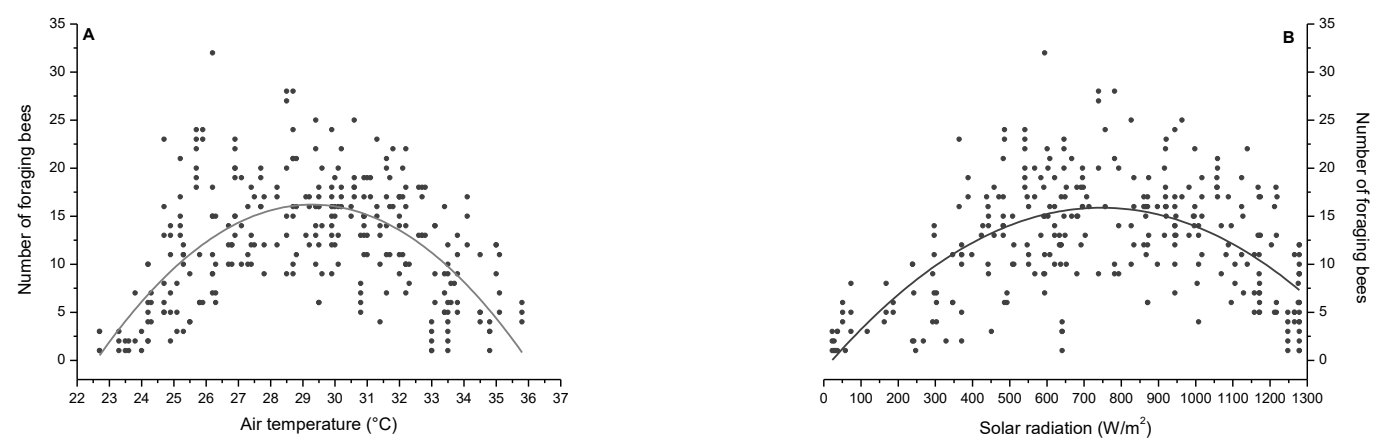

Figure 2 The relationship between the number of Melipona subnitida foraging in an artificial feeder according to the air temperature (A) and solar radiation (B). Source: Souza-Junior (2019)

\section{The distance between the beehive and food source}

Another factor that directly influences the foraging activity of stingless bees is the distance between the hive and the food source (Basari et al 2018). Foraging preference is given to the floral resources closest to the hive. At greater distances, forage bee recruitment only occurs if the resource is highly profitable for the colony (Nieh and Sánchez 2005). However, when food resources are away from the hives, foraging activity will be expensive for bees (Couvillon et al 2015), as the benefit generated by heat gain through solar radiation to save endothermic heat (Stabentheiner and Kovac 2014) can be replaced by the problem of body overheating (Willmer and Stone 2004).

\section{Final Considerations}

Stingless bees establish complex relationships with their thermal environment. Such complexity goes far beyond the air temperature effects. Often neglected, solar radiation affects the body temperature of bees and their foraging activity in tropical environments. 


\section{References}

Abecia JA, Máñez J, Macias A, Laviña A, Palacios C (2017) Climate zone influences the effect of temperature on the day of artificial insemination on fertility in two Iberian sheep breeds. Journal of Animal Behaviour and Biometeorology 5:124-131.

Barbosa MF. Campos LADO, Paixão JFD, Alves RMDO (2016) Padrão de forrageamento e colheita de recursos de abelhas sem ferrão subterrâneas: Geotrigona subterranean (Friese, 1901) (Hymenoptera: Apidae: Meliponini). Papéis Avulsos de Zoologia 56:151-157.

Basari N, Ramli SN, Khairi NSM (2018) Food reward and distance influence the foraging pattern of stingless bee, Heterotrigona itama. Insects 9:E138.

Cortopassi-Laurino M, Imperatriz-Fonseca, VL, Roubik DW, Dollin A, Heard T, Aguilar I, Venturieri, GC, Eardley C, Nogueira-Neto P (2006) Global meliponiculture: challenges and opportunities. Apidologie 37:275-292.

Couvillon MJ, Pearce FCR, Accleton C, Fensome KA, Quah SKL, Taylor EL (2015) Honey bee foraging distance depends on month and forage type. Apidologie 46:61-70.

Da Silva RG, Guilhermino MM, Morais DAEF (2010) Thermal radiation absorbed by dairy cows in pasture. International Journal of Biometeorology 54:5-11.

Ferreira NS, Hrncir M (2012) Thermal tolerance of workers of the stingless bee Melipona subnitida (Apidae, Meliponini). In: X Encontro Sobre Abelhas, 2012, Ribeirão Preto, Brasil. Anais do X Encontro Sobre Abelhas, p. 176.

Giannini TC, Acosta AL, Garófalo AL, Saraiva AM, Alves-dosSantos I, Imperatriz-Fonseca VL (2012) Pollination services at risk: Bee habitats will decrease owing to climate change in Brazil. Ecological Modelling 244:127-131.

Giannini TC, Boff S, Cordeiro GD, Cartolano Jr. EA, Veiga AK, Imperatriz-Fonseca VL, Saraiva AM (2015) Crop pollinators in Brazil: a review of reported interactions. Apidologie 46:209-223.

Hrncir M, Teixeira-Souza VHS, Ferreira NS (2015) Foraging at high temperatures. How bees in the Brazilian Tropical Dry Forest solve this thermal challenge. In: Annual Conference of the Animal Behavior Society, 52 ${ }^{\text {nd }}, 2015$, Anchorage, Alaska. Proceedings of the $52^{\text {nd }}$ Annual Conference of the Animal Behavior Society.

Jaapar MF, Jajuli R, Mispan MR, Ghani IA (2018) Foraging behavior of stingless bee Heterotrigona itama (Cockerell, 1918) (Hymenoptera: Apidae: Meliponini). AIP Conference Proceedings 1940:020037.

Kovac H, Stabentheiner A, Schmaranzer S (2010) Thermoregulation of water foraging honeybees - balancing of endothermic activity with radiative heat gain and functional requirements. Journal of Insect Physiology 56:1834-1845.

Layek U, Karmakar P (2018) Nesting characteristics, floral resources, and foraging activity of Trigona iridipennis Smith in Bankura district of West Bengal, India. Insectes Sociaux 65:117132 .
Macias-Macias JO, Tapia-Gonzalez JM, Contreras-Escareno F (2017) Foraging behavior, environmental parameters and nests development of Melipona colimana Ayala (Hymenoptera: Meliponini) in temperate climate of Jalisco, México. Brazilian Journal of Biology 77:383-387.

Maia-Silva C, Imperatriz-Fonseca VL, Hrncir M (2014) Environmental windows for foraging activity in stingless bees, Melipona subnitida Ducke and Melipona quadrifasciata Lepeletier (Hymenoptera: Apidae: Meliponini). Sociobiology 61:378-385.

Maia-Silva C, Hrncir M, Silva CI, Imperatriz-Fonseca VL (2015) Survival strategies of stingless bees (Melipona subnitida) in an unpredictable environment, the Brazilian tropical dry. Apidologie 46:631-643.

Nieh JC, Sánchez D Effect of food quality, distance and height on thoracic temperature in the stingless bee Melipona panamica. Journal of Experimental Biology 208:3933-3943.

Oliveira FL, Dias VHP, Costa EM, Filgueira MA, SOBRINHO JE (2012) Influência das variações climáticas na atividade de vôo das abelhas jandaíras Melipona subnitida Ducke (Meliponinae). Revista Ciência Agronômica 43:598-603.

Oliveira SEO, Costa CCM, Souza Jr JBF, Queiroz JPAF, Maia ASC, Costa LLM (2014) Short-wave solar radiation level willingly tolerated by lactating Holstein cows in an equatorial semi-arid environment. Tropical Animal Health and Production 46:1413-1417.

Potts G, Biesmeijer JC, Kremen C, Neumann P, Schweiger O, Kunin WE (2010) Global pollinator declines: trends, impacts and drivers. Trends in Ecology \& Evolution 25:345-353.

Rashamol VP, Sejian V, Bagath M, Krishnan G, Archana PR, Bhatta R (2018) Physiological adaptability of livestock to heat stress: an updated review. Journal of Animal Behaviour Biometeorology 6:6272 .

Roubik DW (1989) Ecology and natural history of tropical bees. Cambridge: Tropical Biology Series: Cambridge.

Slaa EJ, Sánchez Chaves LA, Malagodi-Braga KS, Hofstede FE (2006) Stingless bees in applied pollination: practice and perspectives. Apidologie 37:293-315.

Souza-Junior JBF (2019) Termorregulação e atividade de forrageamento de Melipona subnitida no bioma Caatinga. Thesis, Universidade Federal Rural do Semi-Árido.

Stabentheiner A, Kovac H, Hetz S, Käfer H, Stabentheiner G (2012) Assessing honeybee and wasp thermoregulation and energetics New insights by combination of flow-through respirometry with infrared thermography. Thermochimica Acta 534:77-86.

Stabentheiner A, Kovac H (2014) Energetic optimisation of foraging honeybees: flexible change of strategies in response to environmental challenges. PLoS ONE :9:e105432.

Willmer PG, Stone GN (2004) Behavioral, ecological, and physiological determinants of the activity patterns of bees. Advances in the Study of Behavior 34:347-466. 